\title{
IMPLEMENTING LISTEN AND IMITATE TECHNIQUE TO IMPROVE PRONUNCIATION SKILL
}

\author{
Hariani Talib ${ }^{1}$, Anwar $^{2}$, Mujahidah ${ }^{3}$ \\ Institut Agama Islam Negeri (IAIN) Parepare ${ }^{123}$ \\ ary.ani1ky@gmail.com ${ }^{1}$
}

\begin{abstract}
This study aimsto find out the improvement of non-native English students in pronunciation by using Listen and Imitate technique. This technique was selected to enhance the students' ability in pronouncing different sounds from their native language. Listening then imitating the sounds repeatedly will ease the students pronounced them perfectly. This research was quantitative which employed preexperimental research with one group pretest-posttest design. The result of the pre test and post test was then compared to see the improvement of the Student's pronunciation after the treatment using Listen and Imitate Technique. This study found out the use of listen and imitate technique was able to improve students' pronunciation skill significantly. This study also provides a set of suggestion to overcome the students' pronunciation problem.
\end{abstract}

Keywords: listen and Imitate technique, pronunciation 


\section{Introduction}

English as International language is multifunctional. It can be used either for communication and academic use. The use of English in international event such as seminar, presentation, workshop, conference and inter alia have shown how English takes a big part in International communication. It is shown that the awareness of the essential of English has been realized by most of people. Therefore, English is currently grown.

This fact probably does not become any interest of the English learners, or perhaps the teachers in some schools. Most, but not all of teachers concur that the goal of the instruction is to enable the students to understand the language which is served in a form of a text like in banner, poster, pamphlet, or in form of record which is given trough listening, if any, and at least can speak in English or to carry out a conversation in English. All of those must have been elaborated in school syllabus. In fact, one of some factors of the failure of the English learning process is that the English teachers do not give a special treatment of pronunciation as one of important elements of English and other languages in common.

Pronunciation, as an element of language is something that has to be noticed. It is very essential that when the sound is pronounced incorrectly or improperly the problem such a mishearing which in further can cause miscommunication will be such a serious problem. That the pronunciation of the students nowadays is very awful, a word can has different meaning from what it has to. The students do not only have trouble in speaking but also trouble in listening. It is found that the one who can pronounce a sound in a word correctly will have a good listening. It equals to the students' ability in listening. As we know how the dumb have trouble in their listening.

There are a lot of items English have, one of the items is pronunciation. Most students think that pronouncing some words correctly, especially when it is conforming to the native language utterance, is just an impossible thing to do. The belief probably arises because of the fear of trying it. Some strange phonetics which exist in English, but does not exist in native language of the English learner can seem very hard to them to utter. This belief cannot be accused based on the fact that there is such a difficulty in utilizing the proper of pronunciation. It is consented with the saying that the native language of English itself has this difficulty. 
That the pronunciation, does not take a special part in learning process, except in the speaking skill, which is not taught specifically and intensively, the error in pronouncing some sounds can be further organized by practicing to produce the proper pronunciation through some words. Moreover, the use of listen and imitate technique is suggested due to the fact that English learners can adapt the sound more easily trough listening process than reading before in further pronouncing the sound itself.

In accordance with the background above, two research questions were drawn; 1) Is the implementation of listen and imitate technique able to improve the students' pronunciation mastery at the eleventh grade of SMAN 3 Pinrang? 2) How does the implementation of listen and imitate technique improve the students' pronunciation mastery at the eleventh grade of SMAN 3 Pinrang?

Some researchers have carried out research related to students' pronunciation and what they found is shown in the following:

Patti Adank, Peter Hagoort, and Harold Bekkering in their research that titled "Imitation Improves Language Comprehension" found that training with sentences spoken in unfamiliar accent, but only when participants imitated the specific pronunciation of the sentences. In conclusion, by demonstrating that imitation improves action comprehension, the present study ilustrates that imitative behavior in humans during social interaction may also serve to streamline interaction at an abstract communicative level by improving interaction partners' comprehension of each orher language in noisy or ambiguous conditions. These results show that imitation may aid in streamlining interaction by improving spoken-language comprehension under adverse listening conditions (Adank et.al, 2010).

Patti Adank in his research found that the experiment showed a positive effect of imitation on social attractiveness judgements for LE (Lliverpool English), and demonstrated that attitude ratings obtained without audio exposure appeared stereotypical than ratings obtained after audio exposure.

Robin Allot in his research stated that language and imitation are closely related by the intermediation of motor control. Behaviour- based robotics is well-placed to take advantage of neuroscience research focusing on these two major ascpects of human functioning (Allot, 2003). 
From the previous finding above, imitation which has the same meaning with listen and imitate technique are effective in improving pronunciation of the English learners. Therefore, it gives resolute reason of why listen and imitate technique chosen as a good technique to teach pronunciation.

However, an understanding of this term should be noticed in order to have an appropriate step to implement it. According to Structuralism, an ideology of linguistic, which existed in the $19^{\text {th }}$ century, pioneered by Ferdinand de Saussure in Europe,language learning is a habit which is stabilized with training and reinforcing.Language is a skill which is obtained from the circle and then carried out trough imitation and reinforcing method (Saepudin, 2014).

The technique of Listen and Imitate technique involves two skills of language. It is receptive skill trough listening process and productive skill trough speaking or imitating the sounds heard. These two skills connect and support each other. The one who has a good listening will have a good speaking. The one who has a good speaking will have a good reading and writing, inter alia.

Listening is important due to the fact that, someone cannot say something which has never been heard before. So, sounds that people produce is sound that they ever heard before. It is produced by imitating the sound they have heard. Actually this technique is frequently used in our daily life. It is what we have practice when the first time learning language (mother tongue). By listening and listening more, one can imitate the sound and then produce it. People cannot produce what they have never heard before.

Listen and imitate technique is a technique used in the Direct Method in which students listen to a teacher or to record which is provided as a model. The students then imitate it. Listen and Imitate Technique (Direct Method) gained its popularity in the late 1800s and early 1900s. Pronunciation is taught trough intuition and imitation; students imitate a model, the teacher or a recording and do their best to approximate the model through imitation and repetition. This instructional method was based on observation of children learning their first language and of children and adults learning foreign languages in noninstructionalsettings. Successors to this approach are the many so called naturalistic method, including comprehension-based methods that devote a period of instruction solely to listening before any speaking is allowed. Example includes 
Asher's(1977) Total Physical Response and Krashen and Terrell's (1983) Natural Approach (Celce-Murcia, 2010).

Based on the problem faced by the students of SMAN 3 Pinrang in pronouncing sounds in English, the theoretical foundation and framework of Listen and Imitate Technique, the researcher formulated 2 hypothesis; 1) Null Hypothesis $\left(\mathrm{H}_{0}\right)$ : implementing Listen and Imitate Technique is not able to improve students' pronunciation skill at the second year of SMAN 3 Pinrang. 2) Alternative Hypothesis $\left(\mathrm{H}_{\mathrm{a}}\right)$ : implementing Listen and Imitate Technique is able to improve students' pronunciation skill at the second year of SMAN 3 Pinrang.

This research is aimed to find out that implementing Listen and Imitate Technique is able to improve students' pronunciation skill and describe how this technique improves students' pronunciation skill at the second year of SMAN 3 Pinrang.

Besides, this research is expected to give contribution both theoretical and practical benefits. The finding of this research is expected to be used as a feedback for knowledge and science in teaching English especially in teaching pronunciation by applying Listen and Imitate Technique. It is also supposed to be logical consideration to extend and to develop new research related.

\section{Method}

This research was conducted in Senior High School (SMAN) 3 Pinrang that involved the second year students. It took a month in its process including initial study, research activities as well as data analysis.

This research was quantitative. Pre-experimental research with one group pretest-post test design was employed to obtain the result. The effects of treatment were examined by analyzing the difference between the pretest and the posttest scores. No comparison with a control group was provided (Best, 1981).

The population of this research was the second year students of SMAN 3 Pinrang in academic year 2017/2018. The population of this research, the number or the total of population, can be seen in the table below: 
Tabel.1 The total of the second year students of SMAN 3 Pinrang in academic year $2017 / 2018$

\begin{tabular}{ccccc}
\hline \multirow{2}{*}{ No. } & Class & \multicolumn{2}{c}{ Sex } & $\begin{array}{c}\text { Number of } \\
\text { Students }\end{array}$ \\
\cline { 3 - 4 } & & Male & Female & 36 \\
\hline 1 & XI Science 1 & 9 & 27 & 37 \\
\hline 2 & XI Science 2 & 4 & 33 & 37 \\
\hline 3 & XI Science 3 & 8 & 29 & 38 \\
\hline 4 & XI Science 4 & 8 & 30 & 30 \\
\hline 5 & XI Social 1 & 12 & 18 & 30 \\
\hline 6 & XI Social 2 & 20 & 10 & 31 \\
\hline 7 & XI Social 3 & 16 & 15 & 239
\end{tabular}

(Data' source: Documentation of SMAN 3 Pinrang 2017/2018)

In selecting the sample, the researcher applied purposive sampling which the sample was chosen based on specific criteria which are decided by the researcher. Therefore, the sample chosen is the students in XI.IS.1 The total of population is seven classes equals with 239 students and the total of sample is thirty students. This class was chosen in consideration that this class can be representative which this class consists of students in medium level.

The instrument of this research is subjective test. This research was applied in pre-test and post-test segment. The students read thirty words from variant sounds. During the process, the students' voice was recorded.

To analyze the data and test the hypothesis, researcher then processed it by using quantitative analysis with statistical method. The first is scoring students' test. The researcher assessed students' speaking test by using the oral proficiency scoring categories. 
Table 2 Teacher's Rating Scale:

\begin{tabular}{cllc}
\hline Rate & \multicolumn{1}{c}{ Accuracy } & Category \\
\hline 5 & $\begin{array}{l}\text { Pronunciation is only very slightly influenced } \\
\text { by the mother-tongue. }\end{array}$ & Very Good \\
& Pronunciation is still moderately influenced & \\
& by the mother tongue but no serious & Good \\
& phonological errors. & Weak \\
& Pronunciation is influenced by the mother & \\
& tongue but only a few serious phonological & Poor \\
\hline & errors. & Pronunciation seriously influenced by the & Very Poor \\
\hline
\end{tabular}

(Heaton, 1975)

The second is classifying students' scores. The scores results were analyzed by using a scale system from a score range 1-100. In the criteria, scores together with the score range as well as qualitative description were provided as shown in the table below:

Table. 3 Classifying the students score :

\begin{tabular}{ccl}
\hline No & Score Range & Qualitative Descriptions \\
\hline 1. & $86-100$ & Very Good \\
\hline 2. & $71-85$ & Good \\
\hline 3. & $56-70$ & Fair \\
\hline 4. & $41-55$ & Poor \\
\hline 5. & $\leq 40$ & Very poor
\end{tabular}

(Arikunto, 2009)

The third is calculating mean score and standard deviation. In calculating the data, researcher operated Microsoft Excel computer program to present descriptive statistical information.

Finally, the last process is testing the hypothesis. To test the hypothesis, the researcher calculated the test of significance with 0.05 levels of significances with these criteria of testing hypothesis: 1) If t-test $<\mathrm{t}$-table, $\mathrm{H}_{0}$ is accepted and $\mathrm{H}_{\mathrm{a}}$ is rejected 
(implementing Listen and Imitate Technique is not able to improve students' speaking skill); 2) If t-test > t-table, $\mathrm{H}_{\mathrm{a}}$ is accepted and $\mathrm{H}_{0}$ is rejected (implementing Listen and Imitate Technique is able to improve students' pronunciation skill).

\section{Results}

The Pretest was conducted at the first meeting. It was attended by thirty students in XI.IS.1. The result of students' pronunciation score before giving treatment by using "listen and imitate technique", showed that most of the students' pronunciation was seriously influenced by the mother tongue and had serious pronunciation errors.It could be concluded that almost all of the XI IPS 1 students' pronunciation skill was still low because most of students gained fair score.

The posttest was conducted at the last meeting after giving the treatment by implementing Listen and Imitate Technique for four meetings. This test was attended by thirty participants and ran by using the same test in the pretest. The result of students' pronunciation posttest showed the average score of students' pronunciation skill after being taught by Listen and Imitate Technique with good description. The comparison of their scores can be seen in the following table.

The following table shows the percentage of the frequency in pre-test and posttest.

Table 4. The Rate Percentage of the Frequency of the Pre-Test and Post-Test

\begin{tabular}{cccccc}
\hline \multirow{2}{*}{ No. } & \multirow{2}{*}{ Description } & \multirow{2}{*}{ Score } & \multicolumn{2}{c}{ Frequency } & Percentage \\
\cline { 3 - 6 } & & & Pre-test & Post-test & Pre-test \\
\hline 1. & Very Good & $86-100$ & 0 & 10 & $0 \%$ \\
\hline 2. & Good & $71-85$ & 0 & 20 & $0 \%$ \\
\hline 3. & Fair & $56-70$ & 18 & 0 & $60 \%$ \\
\hline 4. & Poor & $41-55$ & 12 & 0 & $40 \%$ \\
\hline 5. & Very Poor & $\leq 40$ & 0 & 0 & $0 \%$ \\
\hline \multirow{2}{*}{ Total } & & 30 & 30 & $100 \%$ \\
\cline { 2 - 5 } & \multicolumn{2}{c}{ Mean } & 57,8 & 6,8 & \\
\cline { 2 - 5 } & Standard Deviation & 83,23 & 3,86 &
\end{tabular}

The table 4 above showed the students' percentage of pretest was most common in fair score namely eighteen students and it was the high percentage $60 \%$, then there is 
no students who are in very good score. It means that the students' pronunciation skill was still low. Whereas the percentage of post test indicated that there was increasing percentage of the students in pronunciation because there were twenty students had gotten good scores with the $66,67 \%$, but in this case, there was no students who got very poor score. It means that there was an increasing percentage after doing pre test up to post test.

Then, the data of pretest and posttest were used to test the hypothesis by using ttest non independent samples with the criteria for the level, significant (p) $5 \%$ and $\mathrm{df}=$ 29 , and the value of the table is 1,729 , while the value of t-test is 10,01 . It means that the t-test value is greater than t-table. Thus, it can be concluded that the students' pronunciation skill is significant better after getting the treatment. So, the null hypothesis $\left(\mathrm{H}_{0}\right)$ is rejected and the alternative hypothesis $\left(\mathrm{H}_{1}\right)$ is accepted.

The improvement of the students' pronunciation was obtained by implementing Listen and Imitate Technique in English class. The researcher asked the students to repeat the sounds based on what they have heard. The teacher read one word by word to be imitated. The way the students imitated the researcher was by imitating every letter in every saying. Therefore, every single letter could be imitated well. After that, the researcher gave correction to mishearing which was done by the students. Then, the researcher explained how to pronounce the words. The researcher read while the students were listening. Finally, the researcher corrected the mispronunciation.

During the treatment process for four meetings, the researcher observed students' pronunciation ability when they studied in the classroom. As Listen and Imitate Technique was implemented, the students showed their attractiveness and interest in learning English. They began to be more confident in uttering English words even though they uttered them with some intervention of mother tongue. Theability to pronounce sounds can be obtained easily and appropriately because even when they made mistake, the opportunity to pronounce the sounds correctly was greater. Once the student pronounced it inappropriately, the teacher, in this case the researcher would repeat the sounds by reading the word list. The students then began to listened and got ready to imitate. This activity would be repeated untill the students was able to pronounce the sounds perfectly. In short, from four treatments, students' quality in pronouncing sounds was increased gradually. 


\section{Discussion}

The first objective of this research is to find out the improvement of the result of pronunciation test which was applied in pretest and posttest. The results revealed that there was statistically significant improvement of students' gain score in pronunciation test after being taught by implementing Listen and Imitate Technique.

The researcher's initial study of students' at the second year revealed that the process English teaching and learning was ineffective which make their speaking proficiency low before being taught by using Listen and Imitate Technique. This problem was then proved when the researcher conducted the pretest. According to their pronunciation test transcription in pretest, students who got poor classification prefer to have serious pronunciaation errors which was influenced by mother tongue intervention.

Listen and Imitate Technique in its implementation showed that the pronounciation of non-native English students of SMAN 3 Pinrang could pronounce the sounds properly. The doubt and fear that first existed as the disturbance of the students' pronunciation skill gradually disappeared. By listening to the teacher pronouncing sounds carefully and the opportunity to imitate the teacher as similar as possible, the students were confident to produce non-existed sounds in their native language. The students are ont only confident to produce sounds but also well-motivated to repeat the sounds. This change, of course, had positive effect to the students pronunciation skill. The serious pronunciation errors and mother tounge intervention could be gradually overcomed. Firstly, the students were able to pronounce the non-existed sounds, such as $/ \theta /$ in the word "thigh" which before was pronounced /t/. It was obtained, of course, by repeatation. Finally, the students then were able to produce appropriate sounds.

\section{Conclusion}

Based on the findings and discussion of this research, it can be concluded that Listen and Imitate Technique is able to improve students' pronunciation skill. The result of testing hypothesis through t-test calculation showed that t-test calculation 10,01is greater than t-table 1,729 which means $\mathrm{H}_{0}$ was rejected and $\mathrm{Ha}$ was accepted. Furthermore, this improvement can be seen in the result of pretest and posttest. The data analysis in pretest and posttes showed that students' gain score increased from 57,8 in 
pretest become 6,8 in posttest which indicated their pronunciation skill increased from fair to good classification.

In addition, the findings showed that this technique improves students' pronunciation skill through the existence of Listen and Imitate Technique which was implemented in English class. The students who were at the first observation showed their doubt and fear for pronunciation mastery became more confident in pronouncing some sounds by the imitating the teacher. The error could be corrected by repeating the words given many times. Finally, these findings indicated students' improvement in pronunciation skill after being taught with Listen and Imitate Technique.

In order to succeed in teaching a language, especially in pronunciation, the English teachers should improve their creativity in teaching pronunciation, for example by using media to attract the students' motivation, using aids to explain the material, various techniques in every meeting in order to make the students enjoy teaching learning process.The teachers can use listen and imitate technique to teach pronunciation and to create variety of teaching learning English process.

The students should be more active and not afraid of making mistakes during teaching learning process, especially in pronunciation. They should practice pronouncing some words, discussing with their friends if they have difficulty in pronouncing sounds, and enjoy uttering many words in English with proper pronunciation repeatedly.This research also can be usedas a reference for other researchers to conduct the next research.

\section{References}

Adank, Patty. (2010). Effects of Imitation on Language Attitudes Associated with regional and Standard Accentsof British English.London:University College London.

Adank, Patty, Peter Hagoort, and Harold Bekkering. (2010)Imitation Improves Language Comprehension.Research Article: Psychological Science Online First. Allot, Robin.(2003).Imitation Language and Speech. AISB convention:University of Aberystwyth Wales.

Arikunto, Suharsimi. (2009). Dasar-DasarEvaluasiPendidikan, EdisiRevisi. Jakarta: BumiAksara 
7nspiring: English Education Journal

Volume I No I Maret 2018

Best,John W. (1981). Research in Education. United Stated of America: Prentice Hall Inc.

Celle Murcia, Marianne, Donna M. Brinton, and Janet M. Goodwin. (2010). Teaching Pronunciation a Course Book and Reference Guide. New York: Cambridge University

Heaton, J.B. (1975). Pronunciation English Language Tests. New York: London and New York

Saepudin. (2014). An Introduction to English Learning and Teaching Methodology. Yogyakarta: Trust Media 